\title{
Validity of React Model Based Learning Devices to Improve Mathematical Communication Ability
}

\author{
$1^{\text {st }}$ Lara Yulia Sastri \\ Postgraduate programUniversitas \\ Negeri Padang \\ Padang, Indonesia \\ larayulia04@gmail.com
}

\author{
$2^{\text {nd }}$ Edwin Musdi \\ Mathematics and Science Faculty \\ Universitas Negeri Padang \\ Padang, Indonesia \\ win_musdi@yahoo.co.id
}

\author{
$3^{\text {rd } H a r d e l i ~}$ \\ Universitas Negeri Padang \\ Padang, Indonesia
}

\begin{abstract}
This study aims to produce learning tools based on the REACT model to improve students' valid communication skills. Learning tools developed in the form of Learning Implementation Plans (RPP) and Mathematics Student Worksheets (LKPD) in grade VIII SMP. The learning model is a REACT model consisting of Relating (associating), Experiencing (experiencing), Applying (applying), Cooperating (working together), and Transferring (transferring). The purpose of the REACT Model is to aim for students to be actively involved physically and mentally and there are activities that can bring students to discover the principles themselves in the material being studied. This learning tool uses the Plomp development model which consists of 3 stages, namely the initial investigation phase (preliminary research), the development phase (development or prototyping phase) and the assessment phase (assessment phase). The learning device is said to be valid if it meets the content and construct validity. The instrument used is a validation sheet that contains aspects of presentation, content and material feasibility, graphics or appearance and language. The results of the experts' validation indicate that the learning device meets valid criteria.
\end{abstract}

Keywords - Learning Device Validity, REACT Model and Mathematical Communication Ability

\section{INTRODUCTION}

Communication is an activity that is carried out by someone to others in conveying ideas and information. This communication is carried out both verbally and in writing. In mathematics learning communication skills include the ability of students to read symbols, images, graphics and express ideas contained in mathematics learning. A learner obtains information in the form of mathematical concepts given by the teacher or obtained from reading, so when that transformation occurs mathematical information from the source to the students[15].

Mathematical communication is the ability of students in terms of explaining an algorithm and unique ways to solve problems, the ability of students to construct and explain the presentation of real-world phenomena graphically, words / sentences, equations, tables, and physical presentation [12]. In the assessment of mathematics communication the aspect assessed is the ability of students to express and interpret mathematical ideas verbally, in writing, or in demonstrations [17]. Communication is an activity that is carried out by someone to others in conveying ideas and information, this communication is carried out both in oral and written [10].

In fact the communication skills of students are still not optimal. This can be seen from several previous studies. That only around $14.28 \%$ or only four students in MTs in Surabaya who have mathematical communication skills are categorized as very good [7].

The low mathematical communication skills of students were also seen in one of the schools including Koto XI Tarusan 1 Middle School, that the students' mathematics learning outcomes and communication tests were still many under the Minimum Limitation Criteria (KKM) which is 75.

Paying attention to the above problems, teachers should use teaching materials developed in accordance with the needs and character of students and develop students' mathematical abilities, especially mathematical communication skills, one of which is the Student Worksheet (LKPD). LKPD is teaching material that has been packaged in such a way that students are expected to be able to study the teaching material independently [14]. Through LKPD, teachers can direct activities carried out by students. Associated with the Student Worksheet (LKPD) that is used is known that students have not used teaching materials in the form of LKPD and there are no educators to make and develop teaching materials in accordance with Permendikbud Number 24 of 2016 which can facilitate students to improve communication skills.

Selection of the right teaching material is one of the factors that can determine the success of the learning process. LKPD is expected to contain activities that help students find their own principles in mathematics and can explore students 'creative ideas in finding concepts, by issuing their ideas orally and in writing, it is hoped that students' mathematical communication can be improved. This LKPD is expected to help teachers and students in carrying out better learning, can make 
students active in asking questions and communicating their ideas.

Given the importance of mathematics lessons, it requires the creativity of a teacher in creating learning methods that can improve students' mathematical communication skills. One that can be used by the teacher is learning with the REACT model (Relating, Experiencing, Applying, Cooperating and Transferring. The REACT model is a learning concept that links the material to be learned with the knowledge already possessed or experiences in everyday life [6]. this can also be applied to the 2013 curriculum because the 2013 curriculum has graduate competencies, one of which is creating communicative students to equip students with mathematical thinking skills such as problem solving, mathematical reasoning, mathematical representation, mathematical connections, and mathematical communication [ 11].

The REACT model was developed referring to the understanding of constructivism because learning with this strategy requires students to engage in various activities that continuously, think and explain their understanding, knowing various relationships between themes and ideas [8]. Constructivism (constructivism) is the basis for thinking (philosophy) contextual approach, namely that knowledge is built by humans little by little, the results of which are expanded through limited contexts [18].

The REACT model shows that the application of the REACT learning model is effective on students' mathematical communication skills [2]. The results showed that the learning outcomes of students using the REACT model were better than using conventional methods [6].

In the Relating stage, students are expected to be able to identify a problem and provide a simple explanation, where the explanation will encourage students to release their ideas. These ideas can be used to build students' basic skills when students experience. So that students can make good conclusions, students can do it in groups. Experiencing (experiencing) means "learning by doing" or learning through exploration, discovery, and creation [4]. At the stage of Applying or applying is the students using the concepts they get in learning [5]. At the Cooperating stage (working together) is learning in the context of sharing, responding, communicating with other students [5]. Correspondingly argues that cooperation is the ability to complete tasks together [3]. When discussing, students are expected to be able to provide further explanations and manage strategies and tactics in applying the concepts being studied in apllying and transferring [2]. While at the stage of Transferring Transferring is the use of knowledge in a new context [5]. Transfering also means connecting what students have learned or what students already know in context [9]. Basically group collaboration includes communication, coordination, cooperation, and exchanging information as much as possible [19]. REACT learning where students are actively involved physically and mentally and there are activities that can bring students to find the principles themselves in the material being studied.

REACT learning will be maximized if the teacher also designs in using additional teaching materials, namely LKPD. Student worksheets (LKPD) designed based on the REACT model can be used by students in constructing their understanding. Students are encouraged to think, provoked to bring out their creative ideas and students will be free to develop their thinking to draw conclusions. Problems or examples given in LKPD are not directly given answers, students are given questions that can lead students to find their own answers. With students answering these questions, students are expected to better communicate the ideas they have. With this, students are expected to be interested and challenged in learning and can improve students' mathematical communication skills. LKPD is also equipped with practice questions. Practice questions are made in the form of mathematical communication skills in the form of essays.

In such a situation, the LKPD based on the REACT model is expected to improve students' mathematical communication skills. The REACT model that is closely related to mathematical communication skills is the Relating and Experiencing model, because it is able to identify a problem and provide a simple explanation, where the explanation will encourage students to issue their ideas which aim to train students' abilities in improving mathematical communication. Based on this description, the author conducted a study on the development of learning tools based on the REACT model to improve mathematical communication skills.

\section{METHODS}

This type of research is development research using the Plomp model, starting from the initial investigation phase (preliminary research), the development phase or prototyping stage, and assessment stage [13]. This journal only discusses the prototype making phase, namely on LKPD validation. Validity is often interpreted with accuracy. Validity is a noun, while validity is an adjective. A learning device is said to be valid if the device can measure what should be measured [1]. In the preliminary study needs analysis, curriculum analysis, concept analysis and analysis of students were carried out. Data collection techniques through observation, interviews with math teachers, questionnaires and initial tests with students of class VIII of Koto XI 1 Junior High School Tarusan. 
The prototype manufacturing phase was carried out by designing the student's worksheet (LKPD) based on the REACT model. The LKPD was developed on the basis of Tessmer's formative evaluation. This assessment consisted of selfassessment, expert validation, individual assessment, small group assessment, and field testing. LKPD which has been developed validated by 5 experts who were called as validator consisting of 3 experts in mathematical education, an expert in educational technology and an expert in Indonesian language. The validators will provide an assessment and suggestions on the design of learning tools to identify weaknesses and strengths, and to take into account expected product specifications using validation sheets.

Data analysis techniques used in this study were analyzed descriptively. In the preliminary research data collection instruments in the form of needs analysis, curriculum, students and concepts, observation sheets and interview guidelines. Validity analysis is performed on the data obtained from the validity instrument results. Validity instruments include self evaluation instruments and validation instruments.

\section{RESULTS AND DISCUSSION}

In the preliminary study, the needs analysis, curriculum analysis, analysis of concepts and analysis of students were conducted. Needs analysis was done to get information about the problems contained in the school's learning both faced by teachers and students. The gathering of information was conducted by doing interviews with teachers, observing the implementation of learning, and giving questionnaires to students. Meanwhile, to see the ability of students, the initial test was conducted. The initial test was conducted to see students' critical thinking ability using problems that were tailored to the indicators of communication skills. Needs analysis was done to gather information about the problems involved in learning mathematics. The information gathering was done by interviewing students and teachers at SMPN 1 Koto XI Tarusan. In addition, the existing learning tools used for learning activities were also observed.

Information about the learning process that fitted well with the learning objectives was set by the program. Obtaining information on the initial condition of the students' mathematical communication skills was done by giving the problems testing mathematical communication skills according to the material that has been studied. The result of the test given to 22 students of class VIII SMP N 1 Koto XI Tarusan revealed that from 22 students only a few students can solve the problem. It seemed that students have not been able to solve the problem of mathematical communication skills.
In curriculum analysis, there was a revision of the Curriculum 2013 for the subjects of mathematics in class VIII SMP. This analysis was necessary, which were about the scope of the material, the learning objectives, the selection of appropriate strategies as a basis for the development of the learning tool expected and used in the REACT model.

Student Analysis, Analysis of students aims to find out the quality of individuals who can be used as guidance in designing learning devices. The focus of the activities carried out on analyzing students is how the characteristics of learners include levels of thinking, learning tendencies, how students learn to use designed learning tools. In this study, students who will be used as subjects are students of class VIII of SMPN 1 Koto XI Tarusan in the academic year 2017/2018.

Analysis of concepts was the identification of essential materials that will be discussed in learning and then systematically organized by linking a concept with other relevant concepts to form a concept. The conceptual analysis aimed to identify the facts, concepts, principles and to determine the content and subject that can be presented on the LKPD model based on the REACT model. The content and subject were adapted from the existing components of the REACT model.

The prototype-making phase begins with designing the LKPD based on the REACT model. This design is called prototype 1 . The design of this LKPD is based on the results of preliminary research that has been carried out. After the REACT-based LKPD was produced, selfevaluation was carried out by the researchers themselves for construct validity and discussed with experts for content validity. Instrument validity is divided into four types, namely content validity, construct validity, concurrent validity and predictive validity [16]. Validation of the contents of the LKPD based on the REACT model was carried out by 5 experts consisting of 3 Mathematics Education experts, 1 Language expert and 1 Educational Technology expert. Validity of the content included the conformity between the manufactured products and certain specified criteria, the conformity with the content of the applicable program, the suitability of the learning device with the program, and the relevance of the device with the objectives of learning. While the validity of the construction meant the adequacy between the products produced and the development elements that have been set. The construction validity of LKPD based on the REACT model was obtained by the preparing the devices based on the characteristics of the subject or the expected behavior of the subject.

In the self evaluation, some errors were found on LKPD, such as: typing errors and punctuation errors. After doing the self-evaluation, LKPD based 
on the REACT model was validated by a validator. Based on the results of errors in the self assessment and validator suggestions, some improvements were performed on LKPD based on the REACT model as follows:

TABLE I.SELF EVALUATION ERRORS AND VALIDATOR FEEDBACK

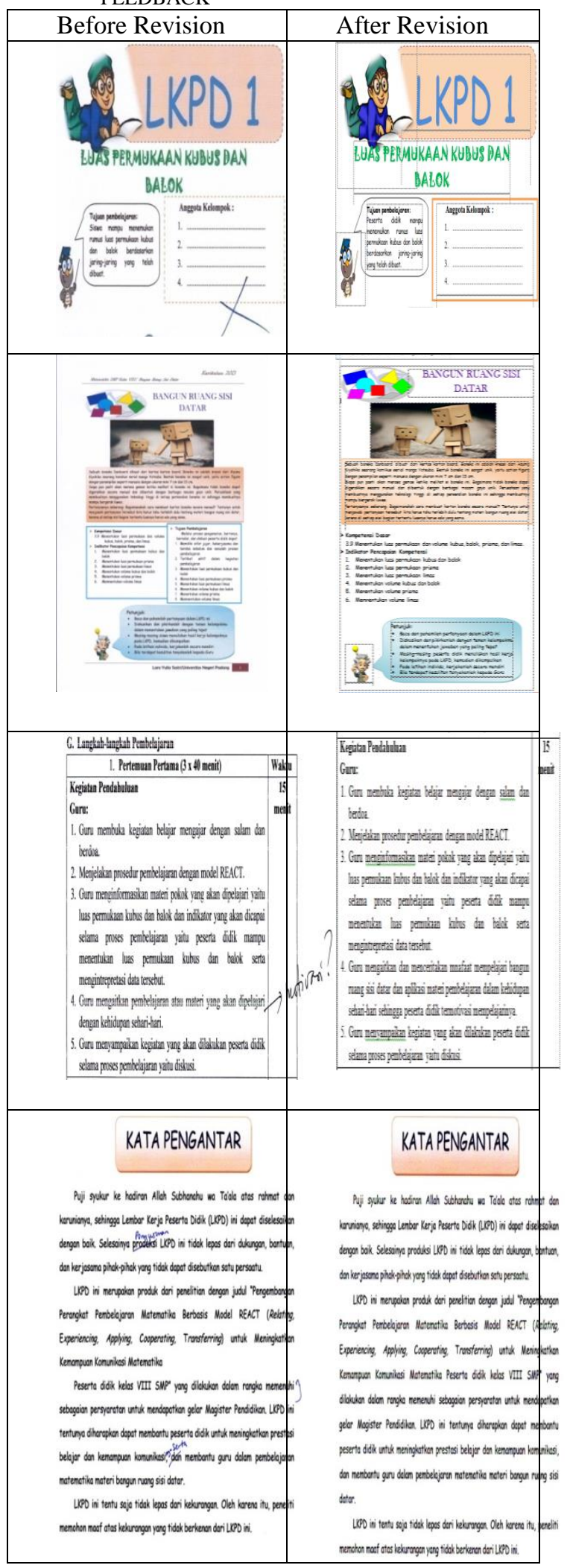

After the repairs were made, the validators provided an assessment of LKPD. Overall, LKPD based REACT model validated by mathematics experts have met the valid criteria with the validity index on the presentation aspect and the content feasibility aspects of 0.88 . This meant that the characteristics and suitability of LKPD with REACT model-based learning can help students to improve mathematical communication skills. The next aspect was the aspect of graphics or appearance. This aspect was validated by one lecturer of Educational Technology. Data analysis of validation result for this aspect was is 0,67 with valid category, thus the display of LKPD was valid to be used. The last aspect validated was the language aspect, which wasvalidated by an Indonesian lecturer. Data analysis of validation result for aspect of language was obtained validity index 0,92 with valid criterion. This meant that language used in LKPD have been communicative and have been valid. The results of the overall validation on each aspect can be seen in Table.

TABLE II. REACT MODEL LKPD VALIDATION RESULTS

\begin{tabular}{|c|c|c|c|}
\hline No. & $\begin{array}{c}\text { Aspect } \\
\text { Validation }\end{array}$ & $\begin{array}{l}\text { Validity } \\
\text { Index }\end{array}$ & Category \\
\hline 1 & Presentation & 0,87 & Valid \\
\hline 2 & $\begin{array}{l}\text { Didactic and Content } \\
\text { (Material) }\end{array}$ & 0,88 & Valid \\
\hline 3 & Challenge (Display) & 0,67 & Valid \\
\hline 4 & Language & 0,92 & Valid \\
\hline \multicolumn{2}{|c|}{ Average Validity Index } & 0,83 & Valid \\
\hline
\end{tabular}

Based on Table II, it can be seen that the average LKPD validation as a whole is 0.83 with valid criteria. So, it can be concluded that LKPD with REACT model based learning is valid.

\section{CONCLUSIONS}

Based on the process and result of the research, it was concluded that these development and design had resulted in LKPD mathematics based on REACT model to improve the communication ability of students in Junior High School that met the valid criteria.

\section{REFERENCES}

[1] Arikunto. Suharsimi, Dasar-dasar evaluasi Pendidikan, Jakarta: Bumi Aksara. 2012. 
[2] Arifin. A. T, "Keefektifan Strategi Pembelajaran React Pada Kemampuan Siswa Kelas VII Aspek Komunikasi Matematis”. Jurnal Kreano, ISSN : 2086-2334 Vol. 5, No 1. 2016.

[3] Atmawinata. D. K, Pendidikan kedinasan. Ilmu dan Aplikasi Pendidikan, bagian IV: Pendidikan Lintas Bidang, Bandung : PT Imperial Bhakti Utama, 2007.

[4] Career. C. D. P, The REACT Strategy. Texas Collaborative for Teaching Excellence. Tersedia pada: http:// info@texascollaborative.org. [Accessed 2007]

[5] Crawford. Michael L, " Teaching Contextually Research, Rationale, and Techniquesn for Improving Student Motivation and Achievement in Mathematics and Science", Texas: CCI Publishing, Inc, ISBN: 1-57837-321-2, 2001.

[6] Dewi. Purnama, Penerapan Strategi React Untuk Meningkatkan Kemampuan Komunikasi Matematis Siswa. Lampung: Universitas Lampung, 2017.

[7] Kurniasari. Ika, "Kemampuan Komunikasi Matematika Siswa dalam Pembelajaran Penemuan Terbimbing pada Materi Teorema Pythagoras", Jurnal UNESA, 2013.

[8] Laelasari, Pengembangan Perangkat Pembelajaran Matematika Melalui Pendekatan Kontekstual dengan Strategi REACT pada Materi Dimensi Tiga Untuk Meningkatkan Komunikasi Matematis Mahasiswa Semester II. Tesis. Semarang: FMIPA Universitas Negeri Semarang, 2010.

[9] Leon. L. C, Persepsi pelajar sekolah menengah teknik terhadap pelaksanaan pengajaran dan pembelajaran kontekstual dalam matematika tambahan, Tesis (tidak diterbitkan). Sekolah Pengajian Siswazah, Universiti Putra Malaysia, 2003.

[10] Morreale. Dkk, "Why Communication is Important: A Rationale for the Centrality of the Study of Communication", Journal of the Association for Communication Administration, 2000. (https://www.natcom.org/uploadedFiles/More_Scholarly_R esources/Chairs_Corner/Making_the_Case_for_and_Advan cing_the_Discipline/PDF-ATD-JACA-

Why Communication is Important \%20Rationale for_Ce ntrality_of_the_Study_of_Communication.pdf) [Accessed 25 Oktober 2016]

[11] NCTM. 2000. Assesment Standards for School Mathematics. Amerika: The National Council of Teachers of Mathematics.Inc

[12] Nugraha. Agi, Pembelajaran Matematika Melalui Metode Personalized System Of Instruction (PSI) untuk Meningkatkan Kemampuan Komunikasi Matematis Siswa SMP. Skripsi FPMIPA UPI Bandung: Tidak Diterbitkan, 2012.

[13] Plomp. T ., N. Nieveen, Educational Design Research. Enshede: Netherlands Institute For Curriculum Development (SLO), 2013.

[14] Prastowo. Andi, Panduan Kreatif Membuat Bahan Ajar Inovatif, Jogjakarta: DIVA Press, 2010.

[15] Sudrajat, Penerapan SQ3R pada Pembelajaran Tindak lanjut untuk Peningkatan Kemampuan Komunikasi dalam Matematika Siswa SMU. Tesis PPS UPI Bandung: tidak dipublikasikan, 2001

[16] Sukardi, Evaluasi Pendidikan Prinsip dan Operasioanlnya. Yogyakarta: Bumi Aksara, 2008.

[17] Suyitno. Amin, Dasar-dasar dan Proses Pembelajaran Matematika I, Semarang: Jurusan Matematika UNNES, 2005.

[18] Trianto, Model-Model Pembelajaran Inovatif Berorientasi Konstruktivistik, Surabaya: Prestasi Pustaka, 2011.

[19] West. M, Effective Teamwork Kerja Sama Kelompok yang Efektif,Yogyakarta: Kanisius, 1998. 